\title{
THE EFFECT OF RELATIONAL CAPITAL ON THE INTELLECTUAL CAPITAL AND FIRM PERFORMANCE NEXUS: EVIDENCE FROM THE JORDANIAN INDUSTRIAL SECTOR
}

\author{
KAMELIA MOH'D KHIER AL MOMANI, NURASYIKIN JAMALUDIN* AND WAN \\ ZANANI@ZALANI WAN ABDULLAH
}

Faculty of Business, Economics and Social Development, Universiti Malaysia Terengganu, 21030 Kuala Nerus, Terengganu, Malaysia.

*Corresponding author: asyikin@umt.edu.my

Submitted final draft: 23 August $2020 \quad$ Accepted: 10 September $2020 \quad$ http://doi.org/10.46754/jssm.2021.07.019

\begin{abstract}
This study aims to investigate the relationship between intellectual capital (IC), measured through value-added intellectual coefficient (VAIC ${ }^{\mathrm{TM}}$ ) and firm performance, measured through market-to-book $(\mathrm{M} / \mathrm{B})$ value ratio of the industrial sector in Jordan, using the relational capital (RC) as a moderating variable. Hierarchical regression models are applied with data collected from 50 industrial companies listed on the Amman Stock Exchange (ASE) during 2008-2017. The results of the analysis show that VAIC ${ }^{\mathrm{TM}}$ has a significant positive effect on the $\mathrm{M} / \mathrm{B}$. In terms of VAIC ${ }^{\mathrm{TM}}$ components, it has been shown that capital employed efficiency (CEE) has a significant positive effect on the $\mathrm{M} / \mathrm{B}$. In addition, $\mathrm{RC}$ is found to have a positive effect on the firm performance. Furthermore, $\mathrm{RC}$, measured through relational capital efficiency (RCE) has a moderating role on the relationship between IC and a firm's performance, which negatively affects the performance of industrial sector in Jordan. Similarly, RC also has a moderating role on the relationship between VAIC ${ }^{\mathrm{TM}}$ components (HCE and SCE) and M/B.

The results of this study can be used as a starting point by policymakers and managers of industrial sector in Jordan to understand the importance of IC components and their interactions, especially the relational capital, in developing strategies to improve the firm performance.
\end{abstract}

Keywords: Intellectual capital, relational capital, value-added intellectual coefficient, firm performance, industrial sector.

\section{Introduction}

In recent years, there has been an emergence of knowledge economies due to the rapid development of technology that occurred at the end of the twentieth century which has led to a shift in the factors of production from land, employment, and physical capital (the traditional concept of capital) to the emergence of a new capital concept, which takes into account the technical expertise of workers in the companies, their intellectual creativity and intelligence, which is known as intellectual capital (IC). This form of capital explains that knowledge and ideas are the basis of wealth creation (Slimani et al., 2016).

IC is an intangible asset, which relies on the knowledge, information, and experience accumulated by corporate employees (Bradley,
1997). It comprises of human capital (HC), which shows the level of education, training, and experience of company employees. This part constitutes $36 \%$ of the total intellectual capital. While structural capital (SC) constitutes $29 \%$, it examines the corporate infrastructure and includes the material elements in the companies. Finally, relational capital (RC) or commonly known as customer capital (CC) makes up 35\% of the total intellectual capital, which examines the company's relationship with its customers (Bontis, 2003; Ramanauskaite \& Rudžionienè, 2013).

Until now, there has been no precise definition of IC, given the diverse factors that affect its nature. One of the most influential definitions of IC was established by Sullivan (2000), who advocated that IC represents 
company knowledge that has the potential to be converted into tangible profit. In addition, researchers found a gap between the book and market value of companies, which refers to IC (Edvinsson, 1997). The definition of IC that is used in the present study is as defined by Pulic (2008): "the people or the employees who have the knowledge and the ability to transform this knowledge to the new products or to create value to the company".

Various scholars have suggested more than 60 classifications and measurement methods of IC (Ramanauskaitė \& Rudžionienè, 2013). The present study utilises VAIC ${ }^{\mathrm{TM}}$ model, designed by the Ante Pulic in 1998. It measures the firms' total value creation efficiency of three key resources: human capital efficiency (HCE), structural capital efficiency (SCE) and capital employed efficiency (CEE). VAIC ${ }^{\mathrm{TM}}$ model has gained widespread use in many countries because it is easy to measure, and at the same time, allows the comparison be made between firms (Fijałkowska, 2014). However, one of the criticisms faced by VAIC ${ }^{\mathrm{TM}}$ is the lack of inclusion of relational capital (RC) in the model (Iazzolino \& Laise, 2013; Momani et al., 2020; Mondal, 2016; Nazari \& Herremans, 2007; Ståhle, Ståhle, \& Aho, 2011).

The importance of RC to firms, is to gain a unique competitive advantage, through obtaining the right feedback from external channels such as customers and suppliers. Besides, RC is the most important component for any firms because it is the main source of income to the companies in sustaining its business activities (Sharabati et al., 2013).

Thus, this study aims to investigate the relationship between VAIC $^{\mathrm{TM}}$ and performance of companies in the industrial sector in Jordan for the period 2008 to 2017. Because of the criticism faced by the VAIC ${ }^{\mathrm{TM}}$ model mentioned earlier, this study further investigates whether relational capital (RC), measured by relational capital efficiency (RCE) moderates the relationship between IC and industrial firms' performance measure, namely the market-tobook $(\mathrm{M} / \mathrm{B})$ value ratio.
Generally, IC related studies in Jordan uses sub-sectors in Amman Stock Exchange (ASE). For example, pharmaceutical manufacturing (Sharabati et al., 2010, 2013; Sharabati \& Nour, 2013), banks (Al-shubiri, 2011; Momani, 2017; Momani \& Nour, 2019)human capital (HCE, hotel industry (Zeglat \& Zigan, 2013, and telecommunication companies (Yaseen et al., 2016). The present study seeks to fill the gap by looking at the main sectors in Jordan, one being the industrial sector. According to the central bank of Jordan 2017 annual report, the industrial sector is the second most important sector, contributing about $21.1 \%$ to Jordan's gross domestic product (GDP).

This study contributes significantly in that it provides information about the firms' performance improvements following the IC application to the managers of the industrial sector, as well as policymakers in Jordan. By utilising the $\mathrm{RC}$ element, it is expected that managers can improve the firms' performance, and sustain companies in the competitive economy (Sharabati et al., 2013).

The remaining part of this paper is dedicated to a literature review and hypotheses development, followed by the research methodology of the study, and the results obtained from regression analysis. The paper ends with a discussion of its findings and conclusion.

\section{Literature Review and Hypotheses Development}

\section{Intellectual Capital and Its Components}

The term IC, was first used in 1969 by Galbraith (Pouraghajan et al., 2013). Generally, an accepted definition of IC is still lacking. Several efforts have been made to develop an acceptable definition for IC. For instance, Bradley (1997) defines IC as a company's capacity to convert knowledge and intangible assets into wealthcreating resources. Marr et al. (2004) define IC as a group of knowledge assets that improve an organisation's competitive position by adding value to it. Stewart and Ruckdeschel (1998) 
argued that IC that is not actively used in the firm is capital that is buried and wasted. Ozkan et al. (2017) mentioned that IC represents intangible assets that are not listed explicitly on a firm's balance sheets but that positively impact the firm's performance.

(Pulic, 2004, 2008) stated that IC is the main resource for creating a competitive advantage and posited that traditional measurement methods of company performance are not appropriate for measuring knowledge performance, as, in his view, traditional measures do not explain the value created from knowledge assets (Iazzolino $\&$ Laise, 2013). Some researchers did not agree with the definition of IC and its components, but most studies divided it into three main components. According to Petrash (1996), the component of IC comprises human capital (HC), structural capital (SC), and relational capital (RC), also known as customer capital (CC).

According to the resource-based view theory, human capital is a unique resource that can drive competitive advantage for the longterm of company's life (Welbourne \& Pardodel-Val, 2009). HC is the core element of the IC because it is the main source of innovation, sustainability and competitive advantage, which depends on the employees who have a higher degree of skills, experiences, talents with higher education (Ngugi, 2013). Human capital can be depicted as the number of company's employees, the employee's education, and years of experience in the company's field work (Lee \& Lin, 2018). Andreeva \& Garanina (2016) define HC as a company's ability to get benefits from the employee's knowledge, skills, and experience, as well as innovations.

The second primary element of the IC is SC which consists of processes, information technology systems and databases of companies. It helps and supports the HC (Chahal \& Bakshi, 2016). In the recent years, interest in SC research has increased rapidly because of the companies' wish to be competitive in the market. It consists of the internal and external capital (Gogan et al., 2015)for most of the organizations, the changes have become more frequent and appear faster than their ability for adjustment and speed in responsibility.Organisations wishing to obtain competitive advantage must understand that these intangible assets represent a greater value than traditional tangible assets. Measuring structural capital (SC. SC supports HC to create the wealth for the company and remains in it after employees leaving the company (Pouraghajan et al., 2013).

The third component of IC is RC, which explains the relationships between the companies and its customers and market channels (Masoomzadeh et al., 2020). RC, also known as customer capital (CC) is based on the knowledge of marketing channels and customers, knowledge from customers and suppliers and related industries (government) (Bontis, 1998). Martí (2003) emphasized that $\mathrm{RC}$ is the relationship between the company and its customers, suppliers, shareholders, and banks including all the marketing strategies of the company and its related trademarks and others.

\section{VAIC $^{T M}$ and Firm Performance}

VAIC $^{\mathrm{TM}}$ model measured the value creation efficiency by using accounting numbers from annual reports (Pulic, 2000)the higher the company's value creation efficiency will be (whereby human capital, as the decisive value creation factor of modern business. This method combined financial and physical capital efficiency and intellectual capital efficiency (ICE) to measure the performance of a company (Pulic, 2000, 2004b, 2008; Ståhle et al., 2011)the higher the company's value creation efficiency will be (whereby human capital, as the decisive value creation factor of modern business. Thus, this method does not measure the value of IC itself but it measures the IC efficiency and financial as well as physical capital impact on the company (Ståhle et al., 2011; Ulum et al., 2014).

Pulic $(2000,2004,2008)$ the higher the company's value creation efficiency will be (whereby human capital, as the decisive value creation factor of modern business mentioned that the suitable tool to measure the value 
creation in the economy knowledge for the companies is the value-added (VA) because it measures the productivity for every type of work at the company's level. VA is defined as an indicator for measuring the employees' knowledge performances. It is computed as the difference between output (i.e. the revenue or the total sales) and input (all cost or expenses except for employee cost) (Pulic, 2004). Because of the decisive role of the employees in the value creation process, the labour expenses cannot be regarded as costs but treated as an investment (Pulic, 2000).

According to Pulic methodology, HCE is basically interpreted as employee expenses and considers it as an HC. This means that this expenditure is not treated as an expense but as an investment of the employees. To determine the HCE value, VA amount is divided into HC (Pulic, 2008). While SC remains in the company after leaving employees, such as programs and software, database and infrastructure, the SCE is measured by dividing SC on the VA(Abdulsalam et al., 2011). Finally, CEE explains the value created per one monetary unit of shareholders capital. It is calculated as VA divided by the book value for the company and refers as $\mathrm{CE}$.

Researchers have studied how IC and its components are related to firms' financial performance. Taking 151 listed companies on the Hong Kong Stock Exchange as the sample, Chu et al. (2011) found a significant and negative relationship between VAIC ${ }^{\mathrm{TM}}$ and $\mathrm{M} / \mathrm{B}$; and a positive relationship between CEE and $\mathrm{M} / \mathrm{B}$, return on equity (ROE), and return of assets (ROA). Murale et al. (2010) examined the effect of $\mathrm{VAIC}^{\mathrm{TM}}$ on the $\mathrm{M} / \mathrm{B}$ ratio of 13 companies in the Bombay Stock Exchange and found a positive significant relationship between VAIC $^{\mathrm{TM}}$, CEE, HCE, SCE and M/B Ratio.

Al-shubiri (2011)human capital (HCE studied IC via VAIC ${ }^{\mathrm{TM}}$ and the relationship with financial performance of 14 commercial banks in Jordan, for the period of 2002-2007 and documented a significant positive relationship with $\mathrm{M} / \mathrm{B}$ ratio and financial performance (ROA, ROE). In the Kingdom of Saudi Arabia and the
Kingdom of Bahrain, a positive relationship between IC and accounting-based performance was noted (Hamdan, 2018). Momani et al. (2020) studied the impact of VAIC ${ }^{\mathrm{TM}}$ on the firm performance for the Jordanian industrial companies through the period 2008-2017 and found a positive relationship between VAIC ${ }^{\mathrm{TM}}$ and firm performance.

Companies that have the ability to exploit their resources effectively will be able to increase their net profits. This leads to an increase in the market value of the company and then an increase the confidence of investors. Therefore, it will increase the share price of the company and the $\mathrm{M} / \mathrm{B}$ ratio (Chatzcoudes, 2013)one of ratios related to market value. For proof this matter (subject. Theoretically, the increase of $\mathrm{VAIC}^{\mathrm{TM}}$ will increase with $\mathrm{M} / \mathrm{B}$ ratio (Chatzoudes et al., 2011b). Most of prior studies which are discussed earlier supported that there is a positive relationship between $\mathrm{VAIC}^{\mathrm{TM}}$ and $\mathrm{M} / \mathrm{B}$. These studies suggested that the increasing gap between $\mathrm{M} / \mathrm{B}$ relation and explained the value of IC that measured by VAIC $^{\text {TM }}$ (Chatzoudes et al., 2011a; Pouraghajan et al., 2013; Kamath, 2015; Nuryaman, 2015; Suhendra, 2016; Smriti \& Das, 2017). Based on the above discussion the study proposes the following hypotheses:

H1: VAIC ${ }^{\mathrm{TM}}$ has a significant relationship with $\mathrm{M} / \mathrm{B}$ ratio in the industrial sector and the Amman Stock Exchange.

It is of particular interest to know how do the different elements of VAIC ${ }^{\mathrm{TM}}$ based on the conceptual model developed by Pulic, (2000)the higher the company's value creation efficiency will be (whereby human capital, as the decisive value creation factor of modern business relate to the $\mathrm{M} / \mathrm{B}$ ratio. Therefore, the following subhypotheses are formulated as follows:

H1a: HCE has a significant relationship with $\mathrm{M} / \mathrm{B}$ ratio in the industrial sector on the Amman Stock Exchange.

H1b: SCE has a significant relationship with $\mathrm{M} / \mathrm{B}$ ratio in the industrial sector on the Amman Stock Exchange. 
H1c: CEE has a significant relationship with $\mathrm{M} / \mathrm{B}$ ratio in the industrial sector on the Amman Stock Exchange.

\section{Relational Capital}

The third component of IC is RC which explains the relationships between the companies and its customers. RC is based on the knowledge of marketing channels and the customers, knowledge from customers and suppliers and related industries (government) (Bontis, 1998). Harris, (2000), Martí (2003) and Starovic \& Marr (2005) emphasise that RC is the relationship between the company and its customers, suppliers, shareholders and banks including all the marketing strategies of the company and its related trademarks and others.

Statistically, if the relationship between the independent variable and the dependent variable depends on another variable, the latter is called a moderating variable (Frazier et al., 2004). According to Hair et al. (2014), the moderator effect in which a third independent variable or the moderator causes the relationship between dependent and independent variable to change, depends on the value of the moderator variable. Therefore, in the present study, the RC becomes the moderating variable, which is measured through RCE (Kehelwalatenna, 2016; Nazari \& Herremans, 2007; Ulum et al., 2017; Vishnu \& Gupta, 2014), to investigate the relationship between VAIC $^{\mathrm{TM}}$ and firm performance in the Jordanian industrial sector.

Previous studies have addressed the VAIC $^{\mathrm{TM}}$ and its relationship with the firm's performance. These studies reveal that some companies still suffer from inefficient utilization for sources because the results showed a different relationship between $\mathrm{VAIC}^{\mathrm{TM}}$ and firm performance. A few studies modified the relationship among VAIC $^{\mathrm{TM}}$ by adding $\mathrm{RC}$ as a new component to ICE, and firms' performance (Bayraktaroglu et al., 2019; Nazari \& Herremans, 2007; Ulum et al., 2014; Vishnu \& Gupta, 2014; Zulkifli et al., 2017).

In recognising the moderating role of $\mathrm{RC}$, the second objective of the present study is looking at the relationship between $\mathrm{VAIC}^{\mathrm{TM}}$ and the firms' performance. The following hypotheses come to fill the gap in the literature with regards to the role of $\mathrm{RC}$ on the VAIC ${ }^{\mathrm{TM}}$ and $\mathrm{M} / \mathrm{B}$.

$\mathrm{H} 2$ : The RC as moderator has an influence on the $\mathrm{VAIC}^{\mathrm{TM}}$ and $\mathrm{M} / \mathrm{B}$ ratio in the industrial sector of the Amman Stock Exchange.

In terms of $\mathrm{VAIC}^{\mathrm{TM}}$ components, the following sub-hypotheses are formulated as follows:

$\mathrm{H} 2 \mathrm{a}$ : $\mathrm{RC}$ as moderator has an influence on the $\mathrm{HCE}$ and $\mathrm{M} / \mathrm{B}$ ratio in the industrial sector of the Amman Stock Exchange.

$\mathrm{H} 2 \mathrm{~b}$ : $\mathrm{RC}$ as moderator has an influence on the $\mathrm{SCE}$ and $\mathrm{M} / \mathrm{B}$ ratio in the industrial sector of the Amman Stock Exchange.

$\mathrm{H} 2 \mathrm{c}$ : $\mathrm{RC}$ as moderator has an influence on the $\mathrm{CEE}$ and $\mathrm{M} / \mathrm{B}$ ratio in the industrial sector of the Amman Stock Exchange. Figure 1 illustrates the conceptual framework for this study. 


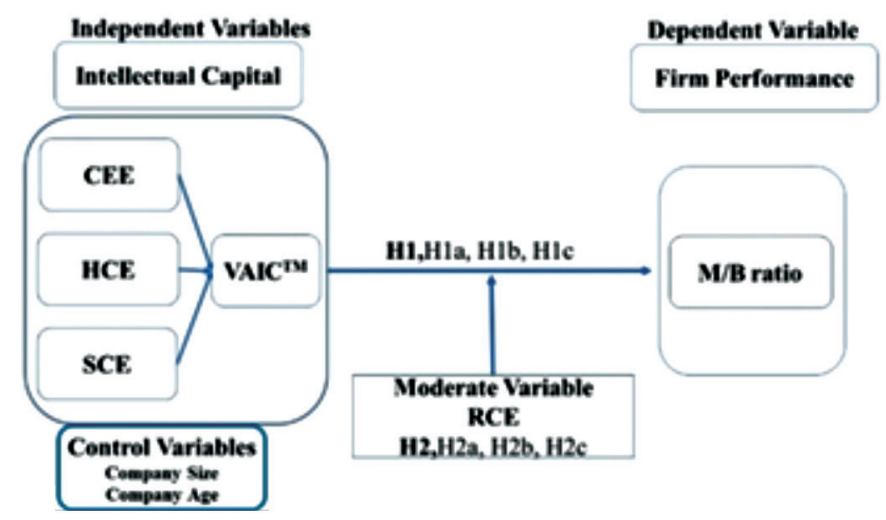

Figure 1: Conceptual Framework

\section{Research Methodology}

\section{Sample Selection}

The population of the present study comprises all 77 companies in the industrial sector listed on the ASE, which consist of 11 sub-sectors. Sample data was collected from annual reports for the 2008-2017 period. The selected companies are based on the following criteria:

1) The industrial company must be listed on the ASE within the period of this study.
2) The shares of the industrial companies must be actively published and traded in ASE during the period of study.

3) The financial year of the industrial companies in ASE must end in 31st of December every year.

Of the 77 industrial companies, 50 companies met the sampling criteria. Table 1 presents the sample for this study. After the exclusions of outliers and 36 observations with abnormal data values, 464 firm-year observations are included in the final sample.

Table 1: Sample of study

\begin{tabular}{lcc}
\hline \multicolumn{1}{c}{ Sub-Sector } & N & \% \\
\hline Pharmaceutical and Medical Industries & 5 & 10 \\
Chemical Industries & 8 & 16 \\
Paper and Cardboard Industries & 1 & 2 \\
Printing and Packaging & 1 & 2 \\
Food and Beverages & 8 & 16 \\
Tobacco and Cigarettes & 2 & 4 \\
Mining and Extraction Industries & 11 & 22 \\
Engineering and Construction & 6 & 12 \\
Electrical Industries & 3 & 6 \\
Textiles, Leathers and Clothing & 5 & 10 \\
\hline \multicolumn{1}{c}{ Total } & 50 & $100 \%$ \\
\hline
\end{tabular}




\section{Variables}

The variables used in the analysis can be broadly classified into four categories: dependent, independent, moderating, and control variables.

\section{Dependent Variable}

The $\mathrm{M} / \mathrm{B}$ ratio (or named the Price to Book ratio) is used to estimate a company's current market value compared to its book value (Maditinos et al., 2011). A firms performance depends on the efficient use of intellectual resources to a large extent, thereby creating gaps between market and book value (Ghosh \& Maji, 2015).

$$
\mathrm{M} / \mathrm{B}=M V i t / B V i t
$$

\section{Independent Variables}

Pulic's VAIC ${ }^{\mathrm{TM}}$ (Pulic, 2008) model is employed to measure the IC in this study. VAIC ${ }^{\mathrm{TM}}$ is the sum of HCE, SCE and CEE. The procedures for calculating VAIC ${ }^{\mathrm{TM}}$ are as follows:

The value-added (VA) is measured as the difference between output and input. The output (OUT) considers all revenue and income from sold products and services. The input (IN) considers all expenses, except employee expenses. VAIC ${ }^{\mathrm{TM}}$ model considered employee expenses as output because of the active role played by the labours in the value creation process (Belkaoui, 2003b; Pulic, 1998, 2004, 2008), Table 2 summarizes the calculation steps of VAIC $^{\text {TM }}{ }_{\text {it }}$.

\section{Moderating Variable}

A mediator variable is defined as a variable that clarifies the relevance between dependent and independent variables (Frazier et al., 2004)line 8 , right column, under the heading Checklist for Evaluating Mediation Analyses Using Multiple Regression, the question incorrectly asks, "Was the relation between the predictor and the outcome (Path b. According to Hair et al., (2014) a moderator effect in which a third independent variable or the moderator causes the relationship between a dependent and independent variable to change, depends on the value of the moderator variable. It is also known as an interactive effect and is like the interaction effect seen in the analysis of variance methods. $\mathrm{RC}$ is used as a moderating variable in this study. It is measured through relational capital efficiency (RCE) (Nazari \& Herremans, 2007; Ulum et al., 2014, 2017). RCE is calculated as follows:

$R C E=\frac{\text { market, sale and adverstising expenses }}{\text { value added }} \ldots .$. (Nazari \& Herremans, 2007; Ulum et al., 2014)

Table 2: Calculation Steps of VAIC ${ }^{\mathrm{TM}}$

\begin{tabular}{ccl}
\hline \multicolumn{1}{c}{ STEP } & VARIABLES & \multicolumn{1}{c}{ EQUATION } \\
\hline STEP 1 & VA & $V A i t=O P i t+E C i t+D i t+I i t+D i v i t+T i t$ \\
STEP 2 & HCE & $H C E_{i t}=V A_{i t} / H C_{i t}$ \\
STEP 3 & SC & $S C_{i t}=V A_{i t}-H C_{i t}$ \\
STEP 4 & SCE & $S C E_{i t}=S C_{i t} / V A_{i t}$ \\
STEP 5 & CEE & $C E E_{i t}=V A_{i t} / C E_{i t}$ \\
STEP 6 & VAIC $^{\mathrm{TM}}$ & $V A I C_{i t}^{T M}=C E E_{i t}+H C E_{i t}+S C E_{i t}$ \\
\hline
\end{tabular}




\section{Control Variables}

This study involves two control variables which are company size and company age (Ahmad \& Ahmed, 2016; Alhassan \& Asare, 2016; Dzenopoljac et al., 2017; Hamdan, 2018; Ozkan et al., 2017; Sherif \& Elsayed, 2016). The company size is measured through the natural logarithm for book value of the total assets in the company (Dang et al., 2018; Harford et al., 2008). Meanwhile, the company age is measured by the current year minus the formation year, and to make the study data more consistent, natural logarithm of age is used because logarithms capture large numbers with small numbers (Yasuda, 2005).

\section{Regression Models}

Focusing on the aim of the study to examine the moderating effect of $\mathrm{RC}$ on the relationship between VAIC ${ }^{\mathrm{TM}}$, its components and the $\mathrm{M} / \mathrm{B}$, hierarchical regression is used. According to Raudenbush and Bryk (2002) and Whitener (2001), hierarchical regression consists of four steps:

Step 1 - To test the control variables (company size and company age).

Step 2 - To test the independent variables with control variables (VAIC $^{\mathrm{TM}}$, HCE, SCE, CEE, and control variables).

Step 3 - To test the independent variables and moderating variable with control variables (VAIC $^{\mathrm{TM}}$, HCE, SCE, CEE, $\mathrm{RCE}$, and control variables).

Step 4 - To test the independent variables and moderating variable with interaction with the independent variables and control variables (VAIC $^{\mathrm{TM}}$, HCE, SCE, CEE, RCE, VAIC ${ }^{\mathrm{TM} *} \mathrm{RCE}$, HCE*RCE, SCE*RCE, CEE*RCE and control variables).

All the models in this study are based on Hausman test panel data that employed the fixed effect model. The models testing for this study are as follows:
Model 1: $\mathrm{M} / \mathrm{B}_{\mathrm{it}}=\alpha 0+\beta 1 \mathrm{VAIC}^{\mathrm{TM}}{ }_{\mathrm{it}}+\beta 2 \log$ Size ${ }_{\text {it }}+\beta 3 \log \mathrm{Age}_{\mathrm{it}}+\varepsilon_{\mathrm{it}}$

Model 2: $\mathrm{M} / \mathrm{B}_{\mathrm{it}}=\alpha 0+\beta 1 \mathrm{HCE}_{\mathrm{it}}+\beta 2 \mathrm{SCE}_{\mathrm{it}}+\beta 3$ $\mathrm{CEE}_{\text {it }}+\beta 4 \log \operatorname{Size}_{\text {it }}+\beta 5 \log \mathrm{Age}_{\mathrm{it}}+\varepsilon_{\mathrm{it}}$

Model 3: $\mathrm{M} / \mathrm{B}_{\mathrm{it}}=\alpha 0+\beta 1 \mathrm{VAIC}^{\mathrm{TM}}{ }_{\mathrm{it}}+\beta 2 \mathrm{RCE}_{\mathrm{it}}$ $+\beta 3 \log \operatorname{Size}_{\mathrm{it}}+\beta 4 \log \mathrm{Age}_{\mathrm{it}}+\varepsilon_{\mathrm{it}}$

Model 4: $\mathrm{M} / \mathrm{B}_{\mathrm{it}}=\alpha 0+\beta 1 \mathrm{HCE}_{\mathrm{it}}+\beta 2 \mathrm{SCE}_{\mathrm{it}}+\beta 3$ $\mathrm{CEE}_{\text {it }}+\beta 4 \mathrm{RCE}_{\text {it }}+\beta 5 \log$ Size $_{\text {it }}+\beta 6 \log$ Age ${ }_{\text {it }}+\varepsilon_{\text {it }}$

Model 5: M/B it $=\alpha 0+\beta 1 \mathrm{VAIC}^{\mathrm{TM}}+\beta 2 \mathrm{RCE}$ ${ }_{\text {it }}+\beta 3 \mathrm{RCE}_{\text {it }}$ *VAIC $^{\mathrm{TM}}{ }_{\text {it }}+\beta 4 \log \operatorname{Size}_{\text {it }}+\beta 5$ $\log$ Age $_{\text {it }}+\varepsilon_{\text {it }}$

Model 6: $\mathrm{M} / \mathrm{B}$ it $=\alpha 0+\beta 1 \mathrm{HCE}_{\mathrm{it}}+\beta 2 \mathrm{SCE}_{\mathrm{it}}+$ $\beta 3 \mathrm{CEE}_{\mathrm{it}}+\beta 4 \mathrm{RCE}_{\mathrm{it}}+\beta 5 \mathrm{RCE}_{\mathrm{it}} * \mathrm{HCE}_{\mathrm{it}}+\beta 6$ $\mathrm{RCE}_{\text {it }} * \mathrm{SCE}_{\mathrm{it}}+\beta 7 \mathrm{RCE}_{\mathrm{it}} * \mathrm{CEE}_{\mathrm{it}}+\beta 8 \log \mathrm{Size}_{\text {it }}$ $+\beta 9 \log$ Age $_{\mathrm{it}}+\varepsilon_{\mathrm{it}}$.

\section{Empirical Analyses}

\section{Descriptive Statistics}

Table 3 presents descriptive statistics of the variables in this study. The result shows that the mean value of VAIC $^{\text {TM }}$ is 1.09085 with a minimum of 0.47748 and a maximum of 1.7917 . The mean value of the HCE is the highest compared with CEE and SCE, which suggest $\mathrm{HC}$ is the driving element of value creation. It is notable that RCE is at low level, with mean value of -0.00002 .

The mean value of $\mathrm{M} / \mathrm{B}$ is -0.01047 , indicating that the Jordanian industrial companies are earning poor return on its assets. In addition, the mean values of company size and age are 16.50316 and 3.00786, respectively.

This descriptive results coincide with results in (Al-shubiri, 2011; Alqadi \& A'alemat, 2018; Hamdan, 2018; Momani et al., 2020; Ulum et al., 2014)structural capital efficiency, and capital adequacy efficiency, but differ from studies such as (Dadashinasab \& Sofian, 2014; Maditinos et al., 2011; Momani \& Nour, 2019; Sherif \& Elsayed, 2016; Zulkifli et al., 2017) using various econometric techniques, the 
Table 3: Descriptive Statistics

\begin{tabular}{|c|c|c|c|c|c|}
\hline Variable & Obs & Mean & Std. Dev. & Min & Max \\
\hline \multicolumn{6}{|c|}{ Independent variables } \\
\hline $\mathrm{VAI}^{\mathrm{CT}} \mathrm{M}$ & 464 & 1.09085 & 0.44716 & 0.47748 & 1.7917 \\
\hline $\mathrm{HCE}$ & 464 & 1.02616 & 0.63374 & 0.11093 & 2.50787 \\
\hline SCE & 464 & -0.00001 & 0.09461 & -0.22475 & 0.92219 \\
\hline CEE & 464 & 0.30629 & 0.22524 & 0.02150 & 0.87348 \\
\hline \multicolumn{6}{|c|}{ Moderating variable } \\
\hline $\mathrm{RCE}$ & 464 & -0.00002 & 0.20263 & -0.19109 & 0.51637 \\
\hline \multicolumn{6}{|c|}{ Dependent variable } \\
\hline $\mathrm{M} / \mathrm{B}$ & 464 & -0.01047 & 0.67574 & -2.0402 & 2.6582 \\
\hline \multicolumn{6}{|c|}{ Control variables } \\
\hline Size & 464 & 16.50316 & 1.35857 & 11.94746 & 20.63084 \\
\hline Age & 464 & 3.00786 & 0.73844 & 0 & 4.18966 \\
\hline
\end{tabular}

VAIC $^{\text {TM }}=$ Value added intellectual coefficient. $\mathbf{H C E}=$ Human capital efficiency. $\mathbf{S C E}=$ Structural capital efficiency. $\mathbf{C E E}=$ Capital employed efficiency. $\mathbf{M} / \mathbf{B}=$ Market to book ratio. $\mathbf{R C E}=$ Relational capital efficiency.

Size $=$ Company size. Age $=$ Company age.

impact of intellectual capital (IC. The reasons being: firstly, the study period, and secondly the study sector.

\section{Correlation Analysis}

Table 4 presents the outcome of correlation analysis for the dependent and independent variables. The correlation analysis shows that $\mathrm{M} / \mathrm{B}$ is positively and significantly correlated with VAIC, HCE, CEE and AGE. Among all components of IC, CEE exhibits significantly positive and highest correlation with the moderating variable, RCE. It also indicates that there is no multicollinearity amongst the variables as none correlates above 0.80 (Gujarati, 2001).

However, the correlation exceeded 0.8 in the case of VAIC ${ }^{\mathrm{TM}}$ and HCE (p-value = $0.955)$, and $\mathrm{VAIC}^{\mathrm{TM}}$ and SCE ( $\mathrm{p}$-value $\left.=0.810\right)$. Nevertheless, this is not a problem because each variable is formulated in a separate regression model. Furthermore, it is confirmed by the variance inflation factors (VIF), which show the values range between 1.04 and 2.60 , within the cut-off points of 10 as reported by Hair et al. (2010). Hence, multicollinearity appears not to be a serious concern in this study. The results of correlation analysis are consistent with the results in Dženopoljac et al. (2016); Dzenopoljac et al.(2017); Ozkan et al. (2017); Yilmaz \& Acar (2018) and Zulkifli et al. (2017), but differ from Smriti \& Das (2017).

\section{Regression Results}

Table 5 shows the results from the panel data regression that employed the fixed effects model after Breusch and Pagan Lagrangian multiplier and Hausman test analysis were carried out. These models have been applied by many previous studies such as Amin \& Aslam (2017); Frazier et al. (2004); Haan et al. (2016); Han \& Li (2015); Hsu \& Wang (2012); Sardo et al. (2018); Tayles et al.(2007) and Zeglat \& Zigan (2013.

Table 6 presents the regression results of testing the effect of RCE on the relationship between $\mathrm{VAIC}^{\mathrm{TM}}$ and $\mathrm{M} / \mathrm{B}$. Model 1 includes $\mathrm{VAIC}^{\mathrm{TM}}$ as the main independent variable, the 
Table 4: Pearson Correlation Analysis

\begin{tabular}{ccccccccc}
\hline Variables & VAIC & HCE & SCE & CEE & M/B & RCE & SIZE & AGE \\
\hline VAIC & 1 & & & & & & & \\
HCE & $.955^{*}$ & 1 & & & & & & \\
SCE & $.810^{*}$ & $.762^{*}$ & 1 & & & & & \\
CEE & $.431^{*}$ & $.389^{*}$ & $.427^{*}$ & 1 & & & & \\
M/B & $.125^{*}$ & $.130^{*}$ & .035 & $.342^{*}$ & 1 & & & \\
RCE & .039 & -.009 & -.030 & $.209^{*}$ & -.040 & 1 & & \\
SIZE & $.439^{*}$ & $.454^{*}$ & $.393^{*}$ & $.209^{*}$ & .026 & -.052 & 1 & \\
AGE & $-.119^{* *}$ & $-.091^{* * *}$ & -.069 & $-.104^{*}$ & $.171^{*}$ & -.0214 & .0502 & 1 \\
\hline
\end{tabular}

* Correlation is significant at the $0.01, * *$ at the 0.05 , and $* * *$ at the 0.1 level.

Table 5: Lagrange and Hausman Test

\begin{tabular}{cccccl}
\hline \multirow{2}{*}{ Model } & \multicolumn{2}{c}{ Lagrange Multiplier } & \multicolumn{2}{c}{ Hausman } & \multirow{2}{*}{ Appropriate Model } \\
\cline { 2 - 5 } & Chi $^{2}$ & Sig. & Chi $^{2}$ & Sig. & \\
\hline $\mathbf{1}$ & 825.84 & 0.0000 & 12.3600 & 0.0062 & Fixed effect \\
$\mathbf{2}$ & 820.71 & 0.0000 & 13.0300 & 0.0111 & Fixed effect \\
$\mathbf{3}$ & 805.17 & 0.0000 & 25.2600 & 0.0001 & Fixed effect \\
$\mathbf{4}$ & 625.16 & 0.0000 & 28.2800 & 0.0000 & Fixed effect \\
$\mathbf{5}$ & 566.33 & 0.0000 & 37.7100 & 0.0000 & Fixed effect \\
$\mathbf{6}$ & 569.69 & 0.0000 & 37.6200 & 0.0000 & Fixed effect \\
\hline
\end{tabular}

results indicate that VAIC ${ }^{\mathrm{TM}}$ is positively and significantly influencing $\mathrm{M} / \mathrm{B}$ (coefficient = 0.13 , p-value $=0.01$ ), thereby supporting $\mathrm{H} 1$. Model 3 includes the moderating variable RCE, the results indicate that $\mathrm{RCE}$ is also positively and significantly influencing $\mathrm{M} / \mathrm{B}$ (coefficient = $0.01, \mathrm{p}$-value $=0.01)$.

Previous studies reported a positive relationship between $\mathrm{RCE}$ and $\mathrm{M} / \mathrm{B}$ (Ulum et al., 2014, 2017; Yilmaz \& Acar, 2018), but on the other hand, there are studies that found insignificant relationship between RCE and M/B (Nimtrakoon, 2015). Model 5 presents the influence of interaction term $\mathrm{RCE}^{*} \mathrm{VAIC}^{\mathrm{TM}}$ on $\mathrm{M} / \mathrm{B}$. The results show significant impacts of the interaction of RCE and VAIC on M/B.

Notably the $\mathrm{R}^{2}$ value in model $5\left(\mathrm{R}^{2}=8.67 \%\right)$ are greater than those in model 1 and 3 . The results corroborate that $\mathrm{RCE}$ has moderating effect on the relationship between $\mathrm{VAIC}^{\mathrm{TM}}$ and $\mathrm{M} / \mathrm{B}$, thereby supporting $\mathrm{H} 2$. The coefficient of RCE*VAIC ${ }^{\mathrm{TM}}$ is significantly negative $(\beta=$ $-0.62, \mathrm{t}=-2.43)$, implying that $\mathrm{RC}$ expenses lower the firm $\mathrm{M} / \mathrm{B}$.

The interaction of variables can be understood by drawing the interaction. A common method that is used to plot the interaction is to choose groups at the mean, at the low and at the high value. We need to examine the regression of dependent variables on independent variables whether at moderate low, or moderate high. If the lines are parallel, there is no interaction; if the lines are not parallel, then there is an interaction (Cohen et al., 2003; Frazier et al., 2004).

Figure 2 clarifies that the company which has a high RCE and high VAIC $^{\mathrm{TM}}$ faces low $\mathrm{M} / \mathrm{B}$. However, if the company has low RCE even though it has high VAIC $^{\mathrm{TM}}$, it has a high $\mathrm{M} / \mathrm{B}$. Taking from M/B point of view, RCE negatively influences the relationship between $\mathrm{VAIC}^{\mathrm{TM}}$ and $\mathrm{M} / \mathrm{B}$ ratio. 
Table 6: Regression results of model 1, 3, and 5

\begin{tabular}{|c|c|c|c|c|c|c|}
\hline \multicolumn{7}{|c|}{$\mathrm{M} / \mathrm{B}_{\mathrm{it}}=\alpha_{0}+\beta_{1} \mathrm{VAIC}^{\mathrm{TM}}{ }_{\mathrm{it}}+\beta_{2} \mathrm{RCE}_{\mathrm{it}}+\beta_{3} \mathrm{RCE}^{*} \mathrm{VAIC}^{\mathrm{TM}}+\beta_{4} \operatorname{logsize}+\beta_{5} \operatorname{logage}+{ }_{\mathrm{zi \textrm {i }}}^{\mathrm{t}}$} \\
\hline \multirow[t]{2}{*}{ Variables } & \multicolumn{2}{|c|}{$\begin{array}{c}\text { Model } 1 \\
\text { Independent } \\
\text { Variables } \\
\end{array}$} & \multicolumn{2}{|c|}{$\begin{array}{c}\text { Model } 3 \\
\text { Dependent Variables }\end{array}$} & \multicolumn{2}{|c|}{$\begin{array}{c}\text { Model 5 } \\
\text { Interaction Variable }\end{array}$} \\
\hline & Coef & T-test & Coef & T-test & Coef & T-test \\
\hline Constant. & -2.01 & $-2.66 * *$ & -2.01 & $-2.27 * *$ & -1.96 & $-2.38^{* *}$ \\
\hline \multicolumn{7}{|l|}{ Control Effect } \\
\hline Size & 0.15 & $3.36^{* * *}$ & 0.15 & $2.82 * *$ & 0.16 & $3.17 * *$ \\
\hline Age & -0.20 & $-3.70 * * *$ & -0.20 & $-3.7 * * *$ & -0.24 & $-4.73 * * *$ \\
\hline \multicolumn{7}{|l|}{ Main Effect } \\
\hline VAIC $^{\mathrm{TM}}$ & 0.13 & $3.45 * * *$ & 0.13 & $3.36^{* * *}$ & 0.12 & $2.83 * *$ \\
\hline \multicolumn{7}{|c|}{ Moderate Effect } \\
\hline RCE & & & 0.01 & $0.08^{*}$ & 0.51 & 1.52 \\
\hline \multicolumn{7}{|c|}{ Interaction Effect } \\
\hline RCE*VAIC $^{\text {TM }}$ & & & & & -0.62 & $-2.43 * *$ \\
\hline $\mathrm{R}^{2}$ & \multicolumn{2}{|r|}{$7.64 \%$} & \multicolumn{2}{|c|}{$7.65 \%$} & \multicolumn{2}{|c|}{$8.67 \%$} \\
\hline $\mathrm{R}^{2}$ change & \multicolumn{2}{|r|}{$0.96 \%$} & \multicolumn{2}{|c|}{$0.01 \%$} & \multicolumn{2}{|c|}{$1.02 \%$} \\
\hline $\mathrm{F}$ & \multicolumn{2}{|c|}{26014.09} & \multicolumn{2}{|c|}{26014.09} & \multicolumn{2}{|c|}{3665.49} \\
\hline Significant F & \multicolumn{2}{|r|}{0.0000} & \multicolumn{2}{|c|}{0.0000} & \multicolumn{2}{|c|}{0.0000} \\
\hline
\end{tabular}

Notes: $* * *$, and $* * *$ significant levels at $1 \%, 5 \%$, and $10 \%$.

VAIC $^{\text {TM}}$ : Value added intellectual coefficient. Size: company size. Age: company age. RCE: relational capital efficiency. RCE*VAIC ${ }^{\mathrm{TM}}$ : interaction between $\mathrm{VAIC}^{\mathrm{TM}}$ and RCE

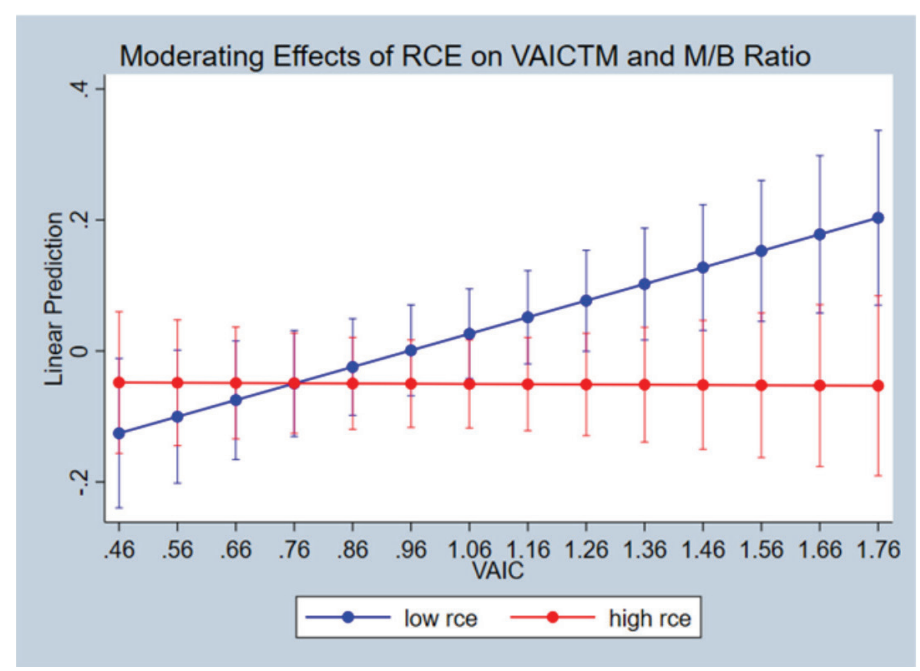

Figure 2: Moderating Effects of RCE on VAIC ${ }^{\mathrm{TM}}$ and M/B 
Table 7 presents the regression results of testing the effect of RCE on the relationship between VAIC ${ }^{\mathrm{TM}}$ components and M/B. Model 2 illustrates the effect of VAIC ${ }^{\mathrm{TM}}$ components on $\mathrm{M} / \mathrm{B}$ ratio. The results found insignificant relationship between $\mathrm{HCE}$, and SCE with M/B. However, a positive significant relationship is found between CEE and M/B. In terms of control variables, company size and company age have a significant positive and negative effect on the $\mathrm{M} / \mathrm{B}$ respectively. The results rejected $\mathrm{H} 1 \mathrm{a}$ and $\mathrm{H} 1 \mathrm{~b}$ but supported $\mathrm{H} 1 \mathrm{c}$.

Adding RCE to model 4 marginally improves the model's explanatory power $\left(\mathrm{R}^{2}\right.$ from 0.0901 to 0.0912 ). The coefficient on RCE is not significant $(\beta=0.13, \mathrm{t}=0.62)$. However, the result indicates a significant positive relationship between SCE, CEE, and M/B. Like model 2 , company size and company age has a significant positive and negative effect on the $\mathrm{M} / \mathrm{B}$ respectively.

Finally, the last regression result, model 6 , shows the effect of interaction between RCE and VAIC ${ }^{\mathrm{TM}}$ components on the M/B. The results show that all three components of VAIC $^{\mathrm{TM}}$ are insignificant. Contrary to model 4 , the coefficient on RCE is significant $(\beta=0.79$, $\mathrm{t}=2.65)$ at 5 percent level. As the interaction between $\mathrm{RCE}$ and $\mathrm{VAIC}^{\mathrm{TM}}$ components are entered into the analysis, $\mathrm{R}^{2}$ increased to 0.1222 .

Table 7: Regression results of model 2, 4, and 6

\begin{tabular}{|c|c|c|c|c|c|c|}
\hline \multicolumn{7}{|c|}{ 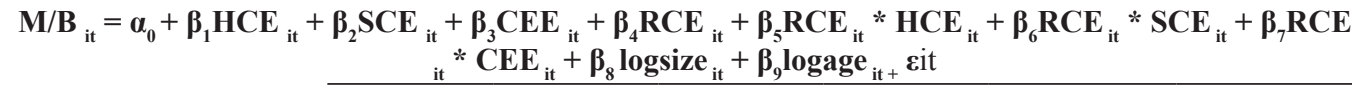 } \\
\hline \multirow[t]{2}{*}{ Variables } & \multicolumn{2}{|c|}{$\begin{array}{c}\text { Model } 2 \\
\text { Independent Variables }\end{array}$} & \multicolumn{2}{|c|}{$\begin{array}{c}\text { Model } 4 \\
\text { Dependent Variables }\end{array}$} & \multicolumn{2}{|c|}{$\begin{array}{c}\text { Model } 6 \\
\text { Interaction Variable } \\
\end{array}$} \\
\hline & Coef & t-test & Coef & t-test & Coef & t-test \\
\hline Constant. & -1.73 & $-2.69 * *$ & -1.60 & $-2.06^{*}$ & -2.24 & $-3.37 * * *$ \\
\hline \multicolumn{7}{|l|}{ Control Effect } \\
\hline Size & 0.14 & $3.88^{* * *}$ & 0.13 & $3.01 * *$ & 0.18 & $4.82 * * *$ \\
\hline Age & -0.22 & $-4.20 * * *$ & -0.23 & $-4.23 * * *$ & -0.27 & $-5.52 * * *$ \\
\hline \multicolumn{7}{|l|}{ Main Effect } \\
\hline HCE & -0.03 & -0.41 & -0.03 & -0.43 & -0.013 & -0.19 \\
\hline SCE & 0.37 & 1.62 & 0.42 & $2.00^{*}$ & 0.46 & 1.53 \\
\hline CEE & 0.42 & $2.73 * *$ & 0.45 & $2.84 * *$ & 0.30 & 1.63 \\
\hline \multicolumn{7}{|c|}{ Moderate Effect } \\
\hline RCE & & & 0.13 & 0.62 & 0.79 & $2.65 * *$ \\
\hline \multicolumn{7}{|c|}{ Interaction Effect } \\
\hline RCE*HCE & & & & & -0.92 & $-3.18^{* *}$ \\
\hline RCE $*$ SCE & & & & & 4.35 & $2.93 * *$ \\
\hline RCE*CEE & & & & & 0.46 & 0.69 \\
\hline $\mathbf{R}^{2}$ & \multicolumn{2}{|c|}{0.0901} & \multicolumn{2}{|c|}{0.0912} & \multicolumn{2}{|c|}{0.1222} \\
\hline $\mathbf{R}^{2}$ change & \multicolumn{2}{|c|}{0.0233} & \multicolumn{2}{|c|}{0.0011} & \multicolumn{2}{|c|}{0.031} \\
\hline $\mathbf{F}$ & \multicolumn{2}{|c|}{277.07} & \multicolumn{2}{|c|}{234.67} & \multicolumn{2}{|c|}{333.51} \\
\hline Significant $\mathbf{F}$ & \multicolumn{2}{|c|}{0.0000} & \multicolumn{2}{|c|}{0.0000} & \multicolumn{2}{|c|}{0.0000} \\
\hline
\end{tabular}

Notes: ***,**, and $*$ significant at the levels $1 \%, 5 \%$, and $10 \%$.

HCE: Human capital efficiency. SCE: Structural capital efficiency. CEE: Capital employed efficiency. RCE: Relational Capital Efficient. Size: company size. Age: company age. RCE*HCE: interaction between $\mathrm{HCE}$ and RCE. RCE*SCE: interaction between SCE and RCE. RCE*CEE: interaction between CEE and RCE 
This reveals that RCE has a moderating effect on the relationship between $\mathrm{VAIC}^{\mathrm{TM}}$ components and $\mathrm{M} / \mathrm{B}$. Furthermore, the interaction between RCE and HCE has a negative impact on M/B, therefore supporting H2a. Meanwhile, the interaction between RCE and SCE has a positive impact on $\mathrm{M} / \mathrm{B}$, thereby $\mathrm{H} 2 \mathrm{~b}$ is supported. However, the effect of RCE and CEE interaction on the $\mathrm{M} / \mathrm{B}$ has become insignificant, thereby rejecting $\mathrm{H} 2 \mathrm{c}$. In addition, company size has a significant positive impact on $\mathrm{M} / \mathrm{B}$, while company age has a significant negative impact on $\mathrm{M} / \mathrm{B}$.
Figure 3 clarifies that the company which has a high RCE and high HCE faces low in $\mathrm{M} / \mathrm{B}$. However, if the company has low RCE, even though it has a high $\mathrm{HCE}$, it has a high $\mathrm{M} / \mathrm{B}$ ratio. From the M/B point of view, RCE may negatively influence the relationship between $\mathrm{HCE}$ and $\mathrm{M} / \mathrm{B}$ ratio. Therefore, the hypothesis $\mathrm{H} 2 \mathrm{a}$ is supported.

Figure 4 clarifies that the company which has a high RCE and high SCE faces high in $\mathrm{M} / \mathrm{B}$. However, if the company has low RCE, even though it has a high SCE, it has a low M/B

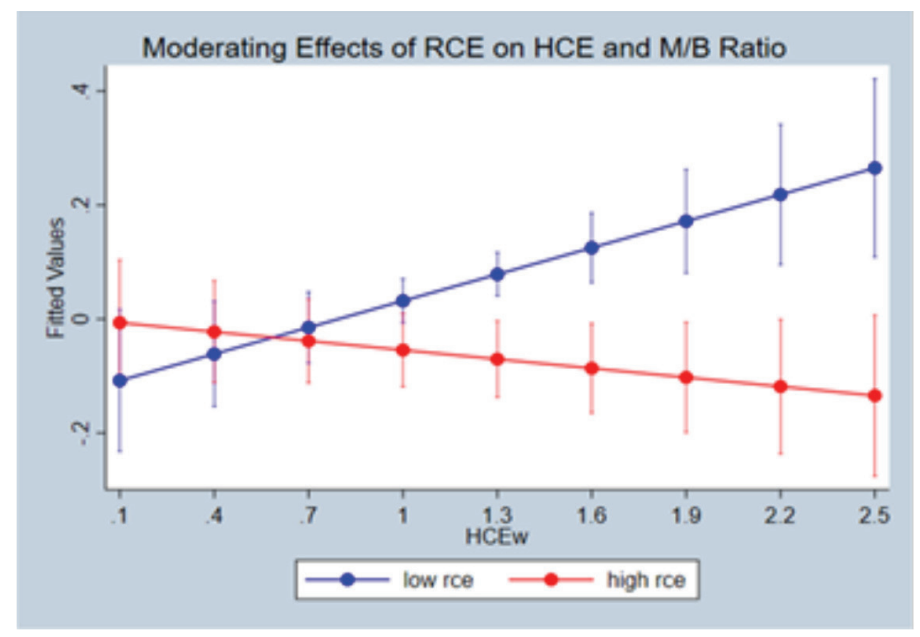

Figure 3: Interaction Effect of RCE on HCE and M/B

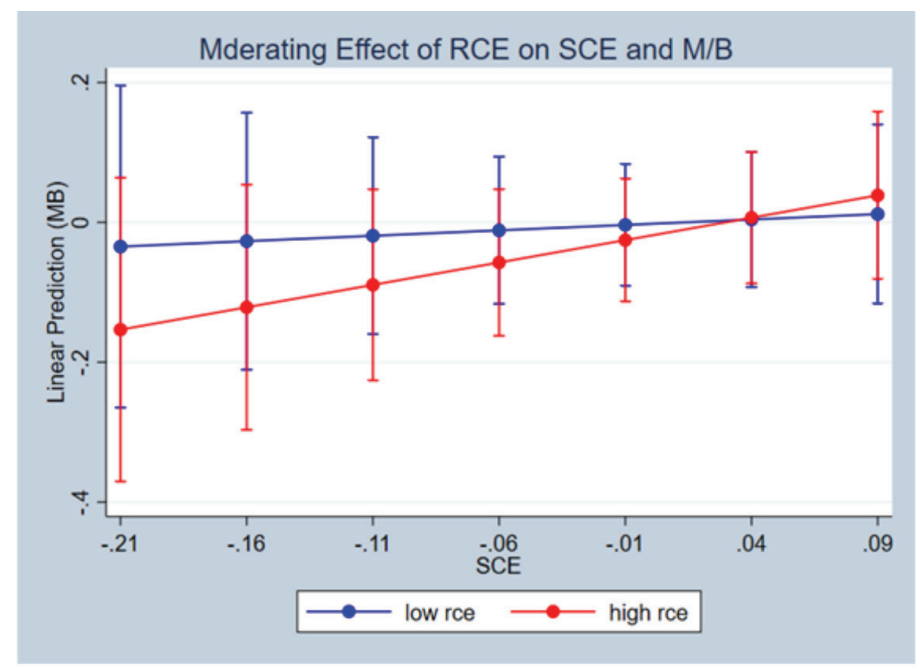

Figure 4: Interaction Effect of RCE on SCE and M/B 
ratio. From the M/B point of view, RCE may positively influence the relationship between $\mathrm{SCE}$ and $\mathrm{M} / \mathrm{B}$ ratio. Therefore, the hypothesis $\mathrm{H} 2 \mathrm{~b}$ is supported.

Figure 5 clarifies that there is no interaction effect of RCE on CEE and M/B ratio. Therefore, hypothesis $\mathrm{H} 2 \mathrm{c}$ is not supported.

\section{Discussion}

The main purpose of the present study is to examine the moderating role of $\mathrm{RC}$, measured by RCE on the relationship between VAIC $^{\mathrm{TM}}$ and its components with $\mathrm{M} / \mathrm{B}$ ratio of industrial companies listed on the Amman Stock Exchange during 2008-2017.

Based on regression analysis, the results in Model 1 indicate that $\mathrm{VAIC}^{\mathrm{TM}}$ has a positive effect on firm performance indicator (M/B), thereby supporting H1. When RCE is entered into the model 3 , the results reveal that RCE also have a positive impact on $\mathrm{M} / \mathrm{B}$, which supports previous studies (Ulum et al., 2014, 2017; Yilmaz \& Acar, 2018)which is between -21.41 until 5.20. Based on M-VAIC scores, performance of IC is classified into four, namely Top Performers, Good Performers, Performers Common, and Bad Performers. The results show that the ranking of three of the four state banks are on the Top Performers category. M-VAIC can be used to measure the ICP all of industries, not only banks. This is also reinforced by the results of the regression that indicate that the value added (VA, but contrary to the finding by Nimtrakoon (2015). As the interaction term $\mathrm{RCE}^{*} \mathrm{VAIC}^{\mathrm{TM}}$ is entered into the model 5, the results show significant impacts of RCE and VAIC interaction on $\mathrm{M} / \mathrm{B}$. Notably the $\mathrm{R}^{2}$ value in model $5\left(\mathrm{R}^{2}=8.67 \%\right)$ are greater than those in model 1 and 3 . The results corroborate that RCE has moderating effect on the relationship between $\mathrm{VAIC}^{\mathrm{TM}}$ and $\mathrm{M} / \mathrm{B}$, thereby supporting H2. The coefficient of RCE*VAIC ${ }^{\text {TM }}$ is significantly negative $(\beta=-0.62, \mathrm{t}=-2.43)$, implying that $\mathrm{RC}$ expenses lower the firm M/B. In addition, a possible explanation for this result may be that non-financial factor affecting the industrial Jordanian companies such as customer satisfaction. Although companies had spent on advertising and promotion to reach the customers, it may not satisfy the customers (Wang \& Chang, 2005).

As illustrated in Table 6, the results in Model 2 found insignificant relationship between HCE, and SCE with M/B. Therefore, $\mathrm{H} 1 \mathrm{a}$ and $\mathrm{H} 1 \mathrm{~b}$ are not supported. However, a positive significant relationship is found between $\mathrm{CEE}$ and $\mathrm{M} / \mathrm{B}$, which supports H1c. This

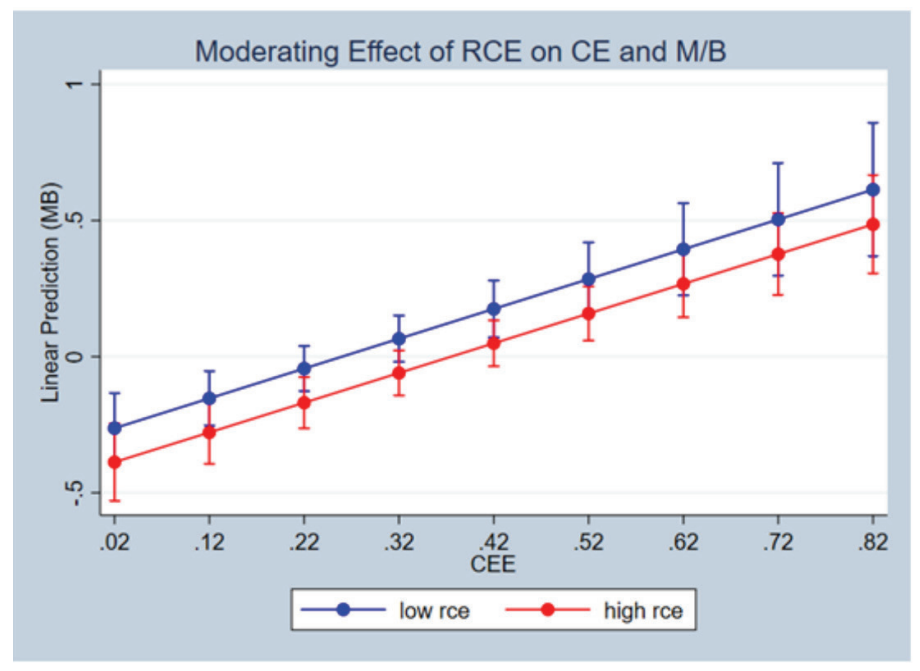

Figure 5: Interaction Effect of RCE on CEE and M/B 
implied that in terms of VAIC ${ }^{\mathrm{TM}}$ components, only the CEE has a positive impact on $\mathrm{M} / \mathrm{B}$. The addition of RCE into model 4 slightly improves the model's explanatory power, but the impact is not significant.

The final model 6 results show that all three components of VAIC ${ }^{\mathrm{TM}}$ are insignificant. $\mathrm{RCE}$ is found to have a moderating effect on the relationship between $\mathrm{VAIC}^{\mathrm{TM}}$ components and $\mathrm{M} / \mathrm{B}$. Furthermore, the interaction between RCE and HCE has a negative impact on $\mathrm{M} / \mathrm{B}$, therefore supporting $\mathrm{H} 2 \mathrm{a}$. This means that, the higher the value of HCE, the lower its M/B. Meanwhile, the interaction between RCE and SCE has a positive impact on $\mathrm{M} / \mathrm{B}$, thereby $\mathrm{H} 2 \mathrm{~b}$ is supported. This means that, the higher the SCE of the companies, the higher their M/B value. However, the effect of RCE and CEE interaction on the $\mathrm{M} / \mathrm{B}$ has become insignificant, thereby rejecting $\mathrm{H} 2 \mathrm{c}$.

\section{Conclusion}

In the era of knowledge economy, IC has been increasingly regarded as a major driver of business performance. The objective of this study is to examine the relationship between IC, measured through $\mathrm{VAIC}^{\mathrm{TM}}$ and the firm performance, measured through market to book $(\mathrm{M} / \mathrm{B})$ value ratio of the industrial sector in Jordan, using the $\mathrm{RC}$ as a moderating variable. The regression analysis results on the data from industrial sector in ASE during 2008-2017 period validate earlier studies and extend the IC literature, especially on the role of $\mathrm{RC}$ as a moderating factor towards firm performance. This study has several important implications.

First, the effect of $\mathrm{RC}$ as a moderator on the relationship between $\mathrm{VAIC}^{\mathrm{TM}}$ and firm performance is consistent with the stakeholder theory because the results show a negative relationship between $\mathrm{VAIC}^{\mathrm{TM}}$ and $\mathrm{M} / \mathrm{B}$. In addition, the effect of $\mathrm{RC}$ on the relationship between VAIC ${ }^{\mathrm{TM}}$ components and the firms' performance show a negative relationship of RC with $\mathrm{HCE}$ and $\mathrm{M} / \mathrm{B}$, and a positive relationship of RC with $\mathrm{SCE}$ and $\mathrm{M} / \mathrm{B}$. These results may be due to the political situation in the Middle East, which directly affects Jordan.

The results of this study provides policymakers with alternative knowledge resources and the means to improve the knowledge resource relationship, especially with regards to human and structural capital. These results are important for managers and business leaders in industrial companies to highlight the importance of IC and supporting RC to enhance the most significant IC components to get better performance in the companies.

Following the results of this study, future research should focus on the $\mathrm{RC}$ and the relationship between $\mathrm{VAIC}^{\mathrm{TM}}$ and firm performance by paying attention to all sectors in the ASE. In addition, studying a different period from the period of this study, two financial and economic crises that affected Jordan's economy also took place during the period under review.

Nevertheless, this study has some limitations that could be improved in the near future research opportunity. First, the results of this study cannot be generalized to the Middle East, because the sample of the present study was restricted to industrial companies listed in ASE only, and the findings are confined to the industrial companies listed in ASE. Next, the study only uses the quantitative data of $\mathrm{VAIC}^{\mathrm{TM}}$, $\mathrm{RC}$, and the $\mathrm{M} / \mathrm{B}$ ratio that are available in the ASE database, published annual reports but ignores the qualitative portions of $\mathrm{VAIC}^{\mathrm{TM}}$ and $\mathrm{RC}$.

Finally, the period for the study comes through two crises; the first one mortgage crisis that affected the Jordanian economy since 20082011, and the second one the Arab Spring since the late 2011.

\section{Acknowledgements}

This research is part of a dissertation which was submitted as partial fulfilment to meet requirements for the degree of Doctor of Philosophy at Universiti Malaysia Terengganu. 


\section{References}

Abdulsalam, F., Al-Qaheri, H., \& Al-Khayyat, R. (2011). The intellectual capital performance of KuwaitiBanks: An application of vaicTM1 Model. IBusiness, 03(01), 88-96. https://doi.org/10.4236/ib.2011.31014

Ahmad, M., \& Ahmed, N. (2016). Testing the relationship between intellectual capital and a firm's performance: An empirical investigation regarding financial industries of Pakistan. International Journal of Learning and Intellectual Capital, 13(2/3), 250. https://doi.org/10.1504/ IJLIC.2016.075691

Al-shubiri, F. N. (2011). Testing the relationship between the efficiency of value added intellectual coefficient and corporate performance at commercial banks in Amman Stock Exchange ( ASE ). Zagreb International Review of Economics \& Business, 14(1), 1-22.

Alhassan, A. L., \& Asare, N. (2016). Intellectual capital and bank productivity in emerging markets: Evidence from Ghana. Management Decision, 54(3), 589-609. https://doi.org/10.1108/MD-01-2015-0025

Alqadi, L., \& A'alemat, N. (2018). The impact of intellectual capital on the accounting disclosure of financial statements in Jordanian Industrial Public Shareholding Companies. Journal of Economics of Business and Finance, 6, 134-156.

Amin, S., \& Aslam, S. (2017). Intellectual capital, innovation and firm performance of pharmaceuticals: A study of the London stock exchange. Journal of Information \& Knowledge Management, 16(02), 1750017. https://doi.org/10.1142/ S0219649217500174

Andreeva, T., \& Garanina, T. (2016). Do all elements of intellectual capital matter for organizational performance? Evidence from Russian context. Journal of Intellectual Capital, 17(2), 397-412. https://doi. org/10.1108/JIC-07-2015-0062
Bayraktaroglu, A., Calisir, F., \& Baskak, M. (2019). Intellectual capital and firm performance: An extended VAIC model. Journal of Intellectual Capital, 20(3), 406425. https://doi.org/10.1108/JIC-12-20170184

Bontis, N. (1998). Intellectual capital: An exploratory study that develops measures and models. Management Decision, 36(2), 63-76. https://doi. org/10.1108/00251749810204142

Bontis, N. (2003). Intellectual capital disclosure in Canadian corporations. Journal of Human Resource Costing \& Accounting, 7(1), 9-20. https://doi.org/10.1108/eb029076

Bradley, K. (1997). Intellectual capital and the new wealth of nations. Business Strategy Review, 8(1), 53-62. https://doi. org/10.1111/1467-8616.00046

Chahal, H., \& Bakshi, P. (2016). Measurement of intellectual capital in the Indian banking sector. Vikalpa, 41(1), 61-73. https://doi. org/10.1177/0256090916629253

Chatzoudes. (2013). The evaluation of the relationship between price ToBook Ratio and accounting variables. International Research Journal of Applied and Basic Sciences, 6(10), 14851488.

Chu, S., Chan, K., Yu, K., Ng, H., \& Wong, W. (2011). An empirical study of the impact of intellectual capital on business performance. Journal of Information \& Knowledge Management, 10(01), 11-21. https://doi. org/10.1142/S0219649211002791

Cohen, J., Cohen, P., West, S., \& Aiken, L. (2003). Applied Multiple Regression/ Correlation Analysis for the Behavioral Sciences (3rd ed.). Lawrence Erlbaum Associates, Publishers.

Dadashinasab, M., \& Sofian, S. (2014). The impact of intellectual capital on firm financial performance by moderating of dynamic capability. Asian Social Science, 10(17), 93-100. https://doi.org/10.5539/ass. v10n17p93 
Dang, C., (Frank) Li, Z., \& Yang, C. (2018). Measuring firm size in empirical corporate finance. Journal of Banking and Finance, 86, 159-176. https://doi.org/10.1016/j. jbankfin.2017.09.006

Dženopoljac, V., Janoševic, S., \& Bontis, N. (2016). Intellectual capital and financial performance in the Serbian ICT industry. Journal of Intellectual Capital, 17(2), 373396. https://doi.org/10.1108/JIC-07-20150068

Dzenopoljac, V., Yaacoub, C., Elkanj, N., \& Bontis, N. (2017). Impact of intellectual capital on corporate performance: Evidence from the Arab region. Journal of Intellectual Capital, 18(4), 884-903. https:// doi.org/10.1108/JIC-01-2017-0014

Edvinsson, L. (1997). Developing intellectual capital at Skandia. Long Range Planning, 30(3), 366-373. https://doi.org/10.1016/ S0024-6301(97)90248-X

Fijałkowska, J. (2014). Value Added Intellectual Coefficient $\left(\mathrm{VAIC}^{\mathrm{TM}}\right)$ as a tool of performance measurement. Przedsiebiorczosc $i$ Zarzadzanie, 15(1), 129-140. https://doi.org/10.2478/eam2014-0010

Frazier, P. A., Tix, A. P., \& Barron, K. E. (2004). Testing moderator and mediator effects in counseling psychology research. Journal of Counseling Psychology, 51(1), 115-134. https://doi.org/10.1037/00220167.51.1.115

Ghosh, S. K., \& Maji, S. G. (2015). Empirical Validity of Value Added Intellectual Coefficient Model in Indian Knowledgebased Sector. Global Business Review, 16(6), 947-962. https://doi. org/10.1177/0972150915597597

Gogan, L. M., Duran, D. C., \& Draghici, A. (2015). Structural Capital - A Proposed Measurement Model. Procedia Economics and Finance, 23, 1139-1146. https://doi. org/10.1016/s2212-5671(15)00503-1
Gujarati, D. N. (2001). Basic econometrics. In Jakarta: Erlangga. (4th ed.). Gary Burke. https://doi.org/10.1016/j.aquaculture. 2013.02.043

Haan, A. A.-A., AL-Sakin, S. A.-K., \& ALsufy, F. J. H. (2016). The effect of Value Added Intellectual Coefficient on firms' performance: Evidence from Jordanian Industrial Sector. Research Journal of Finance and Accounting, 7(14), 163-174.

Hair, J., Black, W., Babin, B., \& Anderson, R. (2014). Multivariate Data Analysis: Pearson New International Edition (7th ed.). In Pharmaceutical Quality by Design: A Practical Approach ( $7^{\text {th }}$ ed.). https://doi. org/10.1002/9781118895238.ch8

Hamdan, A. (2018). Intellectual capital and firm performance: Differentiating between accounting-based and market-based performance. International Journal of Islamic and Middle Eastern Finance and Management, 11(1), 139-151. https://doi. org/10.1108/IMEFM-02-2017-0053

Han, Y., \& Li, D. (2015). Effects of intellectual capital on innovative performance: The role of knowledge-based dynamic capability. Management Decision, 53(1), 40-56. https://doi.org/10.1108/MD-08-2013-0411

Harford, J., Mansi, S. A., \& Maxwell, W. F. (2008). Harford, Mansi, Maxwell - 2008 - Corporate governance and firm cash holdings in the US 拧.pdf. 87, 535-555.https:// doi.org/10.1016/j.jfineco.2007.04.002

Harris, L. (2000). Theory of Intellectual Capital. Advances in Developing Human Resources, 2(1), 22-37. https://doi. org/10.1177/152342230000200104

Hsu, L. C., \& Wang, C. H. (2012). Clarifying the effect of intellectual capital on performance: The mediating role of dynamic capability. British Journal of Management, 23(2), 179-205. https://doi.org/10.1111/j.14678551.2010.00718.x

Iazzolino, G., \& Laise, D. (2013). Value added intellectual coefficient (VAIC): A 
methodological and critical review. Journal of Intellectual Capital, 14(4), 547-563. https://doi.org/10.1108/JIC-12-2012-0107

Iazzolino, G., \& Laise, D. (2015). Value Added Intellectual Coefficient (VAIC). Journal of Intellectual Capital, 14(4), 547-563. https:// doi.org/10.1108/JIC-12-2012-0107

Kamath, G. B. (2015). Impact of intellectual capital on financial performance and market valuation of firms in India. International Letters of Social and Humanistic Sciences, 48(1997), 107-122. https:// doi.org/10.18052/www.scipress.com/ ILSHS.48.107

Kehelwalatenna, S. (2016). Intellectual capital performance during financial crises. Measuring Business Excellence, 20(3), 5578. https://doi.org/10.1108/MBE-08-20150043

Lee, C. C., \& Lin, C. K. (2018). The major determinants of influencing the operating performance from the perspective of intellectual capital: Evidence on CPA industry. Asia Pacific Management Review. $\quad$ https://doi.org/10.1016/j. apmrv.2018.01.006

Maditinos, D., Chatzoudes, D., Tsairidis, C., \& Theriou, G. (2011). The impact of intellectual capital on firms' market value and financial performance. Journal of Intellectual Capital, 12(1), 132-151. https:// doi.org/10.1108/14691931111097944

Marr, B., Schiuma, G., \& Neely, A. (2004). Intellectualcapital-definingkeyperformance indicators for organizational knowledge assets. Business Process Management Journal, 10(5), 551-569. https://doi. org/10.1108/14637150410559225

Martí, J. M. V. (2003). In search of an Intellectual Capital General Theory. Electronic Journal of Knowledge Management, 1(2), 213-226. http://www.ejkm.com/ search/?name $=$ keywords $\&$ value $=$ strategic management
Masoomzadeh, A., Normeza, W., Zakaria, W., \& Masrom, M. (2020). Intellectual capital as key asset in Iranian Automotive Industry. Journal of Environmental Treatment Techniques, 8(1), 429-439.

Momani, K. M. K., Jamaludin, N., Zanani Wan Abdullah, W. Z.@W., \& Nour, A.-N. I. (2020). The effects of intellectual capital on firm performance of industrial sector in Jordan. Humanities \& Social Sciences Reviews, 8(2), 184-192. https://doi. org/10.18510/hssr.2020.8222

Momani, K. M. K., \& Nour, A. N. I. (2019). The influence of intellectual capital on the return of equity among banks listed in Amman Stock Exchange. International Journal of Electronic Banking, 1(3), 220. https://doi. org/10.1504/IJEBANK.2019.099613

Mondal, A. (2016). Application of modified VAICTM Model for measuring intellectual capital performance. International Journal of Research in Finance and Marketing (IJRFM), 6(11), 19-30.

Murale, V., Jayaraj, R., \& Ashrafali. (2010). Impact of intellectual capital on firm performance: A resource based view using VAIC Approach. International Journal of Business Management, Economics and Information Technology, 2(2), 283-292. https://doi.org/10.1109/ PECI.2015.7064933

Nazari, J. A., \& Herremans, I. M. (2007). Extended VAIC model: Measuring intellectual capital components. Journal of Intellectual Capital, 8(4), 595-609. https:// doi.org/10.1108/14691930710830774

Ngugi, J. K. (2013). Influence of intellectual capital on the growth of small and medium enterprises in Kenya. International Journal of Arts and Entrepreneurship, 1-187. http:// ir.jkuat.ac.ke/handle/123456789/1480

Nimtrakoon, S. (2015). The relationship between intellectual capital, firms' market value and financial performance: Empirical evidence from the ASEAN. Journal of 
Intellectual Capital, 16(3), 587-618. https:// doi.org/10.1108/JIC-09-2014-0104

Nuryaman, N. (2015). The influence of intellectual capital on the firm's value with the financial performance as intervening variable. Procedia - Social and Behavioral Sciences, 211(September), 292-298. https:// doi.org/10.1016/j.sbspro.2015.11.037

Ozkan, N., Cakan, S., \& Kayacan, M. (2017). Intellectual capital and financial performance: A study of the Turkish Banking Sector. Borsa Istanbul Review, 17(3), 190-198. https://doi.org/10.1016/j. bir.2016.03.001

Pouraghajan, A., Ramezani, A., \& Mohammadzadeh, S. (2013). Impact of intellectual capital on market value and firms' financial performance: Evidences from Tehran Stock Exchange. World of Sciences Journal, 1(12), 197-208.

Pulic, A. (2000). VAIC TM - an accounting tool for IC management Ante Pulic. Int. J. Technology Management, 20, 702-714.

Pulic, A. (2004a). Do we know if we create or destroy value? International Journal of Entrepreneurship and Innovation Management, 4(4), 349-359. https://doi. org/10.1504/IJEIM.2004.005479

Pulic, A. (2004b). Intellectual capital - does it create or destroy value? Measuring Business Excellence, 8(1), 62-68. https:// doi.org/10.1108/13683040410524757

Pulic, A. (2008). The principles of Intellectual Capital Efficiency - A brief description. Croatian Intellectual Capital Center, Zagreb, February, 2-25. https://doi. org/10.1504/IJEIM.2004.005479

Pulić, A. (2008). The principles of Intellectual Capital Efficiency - A brief description. Croatian Intellectual Capital Center, 76, 1-24. https://doi.org/10.1504/ IJEIM.2004.005479

Ramanauskaitè, A., \& Rudžionienè, K. (2013). Intellectual Capital Valuation: Methods and their classification. Issn Ekonomika, 92(2), 1392-1258.

Sardo, F., Serrasqueiro, Z., \& Alves, H. (2018). On the relationship between intellectual capital and financial performance: A panel data analysis on SME hotels. International Journal of Hospitality Management, 75(July 2017), 67-74. https://doi.org/10.1016/j. ijhm.2018.03.001

Sharabati, A.-A. A., Jawad, S. N., \& Bontis, N. (2010). Intellectual capital and business performance in the pharmaceutical sector of Jordan. Management Decision, 48(1), 105-131. https://doi. org/10.1108/00251741011014481

Sharabati, A.-A. A., Nour, A.-N. I., \& Jabali, S. M. (2013). Relational capital and Jordanian pharmaceutical manufacturing organisations' business performance. European Journal of Business and Innovation Research, 1(2), 85-100.

Sherif, M., \& Elsayed, M. (2016). The impact of intellectual capital on corporate performance: Evidence from the Egyptian Insurance Market. International Journal of Innovation Management, 20(03), 1650034 . https://doi.org/10.1142/ S1363919616500341

Slimani, I., Douli, S., \& Berbaoui, K. (2016). The role of intellectual capital in the Development of Business Organizations: A case study of the IBM. 6(12), 46-54.

Smriti, N., \& Das, N. (2017). Impact of intellectual capital on business performance: Evidence from Indian Pharmaceutical Sector. Polish Journal of Management Studies, 15(1), 232-243. https://doi. org/10.17512/pjms.2017.15.1.22

Ståhle, P., Ståhle, S., \& Aho, S. (2011). Value Added Intellectual Coefficient (VAIC): A critical analysis. Journal of Intellectual Capital, 12(4), 531-551. https://doi. org/10.1108/14691931111181715

Starovic, D., \& Marr, B. (2005). Understanding corporate value: Managing and reporting 
intellectual capital. Chartered Institute of Management Accountants, 6. http://www. valuebasedmanagement.net/articles_cima_ understanding.pdf

Stewart, T., \& Ruckdeschel, C. (1998). Intellectual capital: The new wealth of organizations. Performance Improvement, 37(7), 56-59. https://doi.org/10.1002/ pfi.4140370713

Suhendra, E. S. (2016). The influence of intellectual capital on firm value towards manufacturing performance in Indonesia. International Cpnference on Eurasian Economies, 10(4), 438-445. https://doi. org/10.3923/ibm.2016.438.445

Tayles, M., Pike, R. H., \& Sofian, S. (2007). Intellectual capital, management accounting practices and corporate performance. Accounting, Auditing \& Accountability Journal, 20(4), 522-548. https://doi. org/10.1108/09513570710762575

Ulum, I., Ghozali, I., \& Purwanto, A. (2014). Intellectual capital performance of Indonesian Banking Sector: A modified VAIC (M-VAIC) perspective. Asian Journal of Finance \& Accounting, 6(2), 103. https:// doi.org/10.5296/ajfa.v6i2.5246

Ulum, I., Kharismawati, N., \& Syam, D. (2017). Modified Value-added Intellectual Coefficient (MVAIC) and traditional financial performance of Indonesian biggest companies. International Journal of Learning and Intellectual Capital, 14(3), 207. https://doi.org/10.1504/ IJLIC.2017.086390

Vishnu, S., \& Gupta, V. K. (2014). Intellectual capital and performance of pharmaceutical firms in India. Journal of Intellectual Capital, 15(1), 83-99. https://doi. org/10.1108/JIC-04-2013-0049

Wang, W.-Y. Y., \& Chang, C. (2005). Intellectual capital and performance in causal models. Evidence from the information technology industry in Taiwan. Journal of Intellectual
Capital, 6(2), 222-236. https://doi. org/10.1108/14691930510592816

Welbourne, T. M., \& Pardo-del-Val, M. (2009). Relational capital: Strategic advantage for Small and Medium-Size Enterprises (SMEs) through negotiation and collaboration. Group Decision and Negotiation, 18(5), 483-497. https://doi.org/10.1007/s10726008-9138-6

Yaseen, S. G., Dajani, D., \& Hasan, Y. (2016). The impact of intellectual capital on the competitive advantage: Applied study in Jordanian telecommunication companies. Computers in Human Behavior, 62(November 2017), 168-175. https://doi. org/10.1016/j.chb.2016.03.075

Yasuda, T. (2005). Firm growth, size, age and behavior in Japanese manufacturing. Small Business Economics, 24(1), 1-15. https:// doi.org/10.1007/s11187-005-7568-y

Yilmaz, I., \& Acar, G. (2018). The effects of intellectual capital on financial performance and market value: Evidence from Turkey. Eurasian Journal of Business and Economics, 11(21), 117-133.https://doi.org/ https://doi.org/10.17015/ejbe.2018.021.07

Zeglat, D., \& Zigan, K. (2013). Intellectual capital and its impact on business performance: Evidences from the Jordanian hotel industry. Tourism and Hospitality Research, 13(2), 83-100. https://doi. org/10.1177/1467358413519468

Zia, M., Muhammad, H., Arbab, S., Shahzad, A., \& Bilal, S. (2014). VAIC and firm performance: Banking sector of Pakistan. Information and Knowledge Management, 3(4), 100-107.

Zulkifli, N. S., Abdul Shukor, Z., \& Che Abdul Rahman, M. R. (2017). Intellectual capital efficiency and firm performance in Malaysia: The effect of Government Ownership. Asian Journal of Accounting and Governance, 8(Special Issue), 93105. https://doi.org/10.17576/AJAG-201708SI-09 